\title{
Planned resettlement to avoid climatic hazards: What prospects for just outcomes in China?
}

Brooke Wilmsen $^{1}$ and Sarah Rogers ${ }^{2}$

Planned resettlement is being widely considered as a response to the impacts of climate change. As many millions of people are expected to be displaced in the coming decades, scholars and policymakers are searching for precedence to inform their research and planning, particularly from experiences of Development-Induced Displacement and Resettlement (DIDR). Nowhere in the world is DIDR and other closely related forms of planned resettlement more prevalent than in China: an estimated 78 million people have been displaced by development projects over the last six decades. While planned resettlement has consistently been shown to cause impoverishment, the Chinese state views it as the answer to a multitude of social ills including poverty, environmental damage, low levels of domestic consumption, and most recently, climate change, providing impetus to the normalisation of resettlement as adaptation. This paper examines the prospects for just outcomes in resettlement projects by examining distributive justice at multiple scales in existing resettlement practice in China. It finds that due to the interplay between resettlement and questions of procedural justice, prospects for just outcomes are quite limited, and that in order to achieve fair adaptation, alternatives to planned resettlement should be emphasised.

Key words: relocation, procedural justice, distributive justice, adaptation, climate change

${ }^{1}$ Department of Social Inquiry, La Trobe University, Bundoora, 3086, Australia.

${ }^{2}$ Centre for Contemporary Chinese Studies, The University of Melbourne, Parkville, 3010, Australia.

This is the author manuscript accepted for publication and has undergone full peer review but has Acknowledgements Brooke Wilmsen gratefully acknowledges Australian Research Council Grant may Deat to differences getween this vercion and the Version of Reco rd. Please cite this article as doi: 10.1111/apv.12232 
Autònoma de Barcelona, Dr Fiona Miller, Macquarie University and Dr Andrew van Hulten, La Trobe University, for helpful comments.

This article is protected by copyright. All rights reserved. 


\section{Planned resettlement to avoid climatic hazards: What prospects for just outcomes in China?}

Brooke Wilmsen $^{1}$ and Sarah Rogers ${ }^{2}$

Planned resettlement is being widely considered as a response to the impacts of climate change. As many millions of people are expected to be displaced in the coming decades, scholars and policymakers are searching for precedence to inform their research and planning, particularly from experiences of Development-Induced Displacement and Resettlement (DIDR). Nowhere in the world is DIDR and other closely related forms of planned resettlement more prevalent than in China: an estimated 78 million people have been displaced by development projects over the last six decades. While planned resettlement has consistently been shown to cause impoverishment, the Chinese state views it as the answer to a multitude of social ills including poverty, environmental damage, low levels of domestic consumption, and most recently, climate change, providing impetus to the normalisation of resettlement as adaptation. This paper examines the prospects for just outcomes in resettlement projects by examining distributive justice at multiple scales in existing resettlement practice in China. It finds that due to the interplay between resettlement and questions of procedural justice, prospects for just outcomes are quite limited, and that in order to achieve fair adaptation, alternatives to planned resettlement should be emphasised.

Key words: relocation, procedural justice, distributive justice, adaptation, climate change

\footnotetext{
${ }^{1}$ Department of Social Inquiry, La Trobe University, Bundoora, 3086, Australia.

${ }^{2}$ Centre for Contemporary Chinese Studies, The University of Melbourne, Parkville, 3010, Australia.
} 


\section{Acknowledgements}

Brooke Wilmsen gratefully acknowledges Australian Research Council Grant DE120101037 that partly funded this research and Dr Sonia Graham, Universitat Autònoma de Barcelona, Dr Fiona Miller, Macquarie University and Dr Andrew van Hulten, La Trobe University, for helpful comments.

Planned resettlement is being widely considered as a response to the impacts of climate change. As many millions of people are expected to be displaced in the coming decades, scholars and policymakers are searching for precedence to inform their research and planning, particularly from experiences of Development-Induced Displacement and Resettlement (DIDR). Nowhere in the world is DIDR and other closely related forms of planned resettlement more prevalent than in China: an estimated 78 million people have been displaced by development projects over the last six decades. While planned resettlement has consistently been shown to cause impoverishment, the Chinese state views it as the answer to a multitude of social ills including poverty, environmental damage, low levels of domestic consumption, and most recently, climate change, providing impetus to the normalisation of resettlement as adaptation. This paper examines the prospects for just outcomes in resettlement projects by examining distributive justice at multiple scales in existing resettlement practice in China. It finds that due to the interplay between resettlement and questions of procedural justice, prospects for just outcomes are quite limited, and that in order to achieve fair adaptation, alternatives to planned resettlement should be emphasised.

Key words: relocation, procedural justice, distributive justice, adaptation, climate change 


\section{Introduction}

It is widely accepted that the impacts of climate change will displace some people and communities, and that those lacking resources will require assistance to move (Barnett and Webber, 2010; Asian Development Bank, 2012; Wilmsen and Webber, 2015). That this assistance should be in the form of planned resettlement projects is an idea that is gaining traction. The UNFCCC's Taskforce on Displacement is currently developing recommendations to avert, minimise, and address climate-related displacement, which includes planned relocation (Warsaw International Mechanism Executive Committee, 2017). A recent report by the Brookings Institution and UNHCR suggests that planned relocation will be needed once communities have passed a 'risk threshold' beyond which it is no longer safe for people to remain in place, and that relocation is less expensive than assisting people to rebuild their lives post-disaster (Brookings and UNHCR, 2015). Elsewhere it has been suggested that international adaptation funding mechanisms be used to fund resettlement schemes (McAdam and Ferris, 2015). These discussions and other publications (for instance de Sherbinin et al., 2011) have begun to position resettlement as a logical adaptive response to the impacts of climate change.

In contrast to this normalisation of resettlement as climate change adaptation, a number of scholars have urged caution based on decades of experience of Development-Induced Displacement and Resettlement (DIDR) and its correlates. Barnett and Webber (2009) recommend that communities should not be resettled

This article is protected by copyright. All rights reserved. 
unless absolutely necessary, in large part because powerful actors may invoke climate change in order to conduct forced migrations for other political or economic reasons. From the extensive literature on DIDR, Wilmsen and Webber (2015) draw two key lessons for climate change adaptation policy: avoid resettlement wherever possible, and, where not possible, treat resettlement as requiring more than just material compensation. Mathur (2015) makes a number of recommendations based on the historical successes and failures in DIDR, including undertaking resettlement as a last resort, preparing detailed resettlement plans, ensuring adequate budget provision, securing appropriate land for resettlement, and moving people with their communities. Rogers and Xue (2015) argue resettlement has the potential to be maladaptive, because vulnerability to climate change is not accounted for in existing resettlement planning, including in the selection of resettlement location. While the principle of resettlement as a last resort has been reiterated by the Asian Development Bank (2012), there is little evidence that the institutions that will inform and drive climate-induced resettlement are taking seriously the risks of maladaptation or asking questions about justice in climate resettlement.

Amidst this debate, policymakers and scholars will almost certainly look to China for precedent. China resettles more people than any other country in the world: an estimated 78 million people were displaced by development projects over the previous six decades. Legislation and policies to support land acquisition and resettlement for development projects have been gradually refined, and China has sought to internalise international best practice in resettlement (Cernea, 2016). China is also unique in the way it has reshaped the notion of resettlement and extensively deployed it as a solution to various problems. In DIDR there was a gradual shift from "resettlement with compensation only" to "resettlement with development" (Cernea and Maldonado 2018 p.3), but resettlement also occurs as a development project in itself: for poverty alleviation, environmental degradation, low levels of domestic consumption, and most recently, climate change adaptation. Rather than a phenomenon to be avoided due to the risks of causing impoverishment, resettlement is 
now viewed as remedy.

By posing the question 'what prospects exist for just outcomes in planned climateinduced resettlement', we hope to further these debates about the possibilities and limits of resettlement as adaptation. Specifically, this paper aims to examine distributive justice at multiple scales in existing resettlement practice in China. What we find is that there are limited prospects for distributive justice: resettlement is a highly politicised process that appears to produce, redistribute or exacerbate inequalities at multiple scales. Our analysis and reflections on procedural justice reinforce the principle that resettlement should only ever be considered a last resort.

The paper proceeds as follows. We first discuss the literature on climate justice and fair adaptation, drawing from this an emphasis on distributive justice at multiple scales. We then assess the extent to which these discussions take place in the resettlement literature. Following this literature review we present examples of distributive justice (or lack thereof) at multiple scales, drawing on two completed resettlement projects in the provinces of Hubei and Shanxi: one dam-induced resettlement and one for poverty alleviation purposes. While the justification for each of these resettlements (dam construction and poverty alleviation) is different, the means (resettlement with development) are shared. In the discussion we consider questions of procedural justice, and in keeping with the principle that resettlement should be a last resort, briefly outline alternative adaptive strategies.

\section{Climate justice and fair adaptation}

There are two dominant frames in the literature on climate justice. The first is a responsibility frame, concerned with historical emissions and burden sharing (Risse, 2009; Fisher, 2012). Here richer nations are called upon to provide assistance to developing nations in recognition of the harm caused by their consumption and production patterns (Paavola and Adger, 2006; Vanderheiden, 2008). These calls for distributive justice at the international scale are discussed in terms of emission rights 
(Meyer et al., 2006) or responsibilities to future generations (Page, 2006) and burden sharing rules (Ringius et al., 2002). The second is a rights-based frame, which recognises that climate change violates basic human rights, which must be protected and enforced (Schlosberg and Collins, 2014; Schlosberg, 2012; Johnson, 2012). Given that both of these frames are tied to notions of global citizenship, universalism and supranational governance, the climate justice literature tends to be preoccupied with the international scale (Barrett, 2013; Thomas and Twyman, 2005). As such, it does not adequately capture the multiple, spatially grounded experiences of climate justice that are bound up with histories, power, and the politics of development (Fisher, 2012).

A smaller sub-set of studies does consider justice at other scales. These studies interrogate notions of fairness in adaptation strategies recognising that not only are the impacts of climate change uneven, but so are the effects of adaptation interventions. An early approach was to simply define fair adaptation as adaptation that reduces the vulnerability of the most vulnerable (Adger, 2006). More recently, Graham et al. (2015) have detailed the multiple dimensions of justice in the context of adaptation to sea-level rise, including intertwined notions of distributive justice (the effects of adaptation on individuals and how this varies within a community) and procedural justice (the process through which decisions on adaptation are made and by whom). This kind of framework recognises that adaptation projects are not simply technical interventions but are socially and politically produced. Distributive justice must account for the inequitable social and political conditions that drive differences in need and outcomes (O'Brien and Leichenko, 2003; Thomas and Twyman, 2005), while procedural justice asks questions about recognition, hearing, participation, policy-making, and the distribution of power (Paavola, 2008; Popke et al., 2016).

Despite calls for multi-scalar analyses of climate change adaptation strategies (see Fisher, 2012, Adger et al., 2005; Adger, 2001), scale remains something of a lacuna in the climate justice literature. While the dominant international framings of climate 
justice are now complemented by place-based analyses of multiple dimensions of justice, such a polarisation is not particularly productive. If climate change adaptation can reflect and reproduce inequities across space and time, and within and between households, communities, and other groups, then an analysis of distributive justice must be multi-scalar. And while the considerable geographical literature on the politics of scale is not within the scope of this paper, we do not wish to reinforce an understanding of scale as an inert, nested hierarchy. The socio-political conditions in which adaptation projects - including planned resettlements - occur, the ideas and practices on which they are based, and the effects that they have increasingly reflect hybrid, territorially disintegrated, and transnational networks (Bulkeley 2005).

\section{Resettlement and climate justice}

We find that to date there has been little dialogue between the literature on resettlement and that on climate justice. Questions of justice have begun to frame broader discussions of climate migration - Bettini et al. (2016) and Felli (2013), for instance, critique the language of individual preparedness, resilience, and opportunity that draws attention away from inequities in political, social, and economic power but there has been no discussion of the justice implications of resettlement as an adaptive strategy. For the reasons outlined below, this is long overdue.

While typically associated with mass evictions as a result of dams and other major infrastructure projects, planned resettlement has come to be a highly technocratic, managed, versatile, and pervasive practice. For two decades resettlement has been envisaged as a development opportunity in its own right (Cernea, 1997); that is, resettlers do not simply endure resettlement, but are supposed to enjoy the benefits of development through resettlement projects. Despite a long tradition of critical development scholarship stemming from postcolonial and poststructural critiques (see for instance Ferguson, 1994; Escobar, 1995; Kothari, 2005; Goldman, 2005; Li 2007), 
the idea of resettlement as development has proceeded largely uncontested (for important exceptions see Levien (2017) and Vandergeest (2003)). As such, in the mainstream literature resettlement is assumed to be an apolitical, technical endeavour that is largely unavoidable, and that if managed correctly, can have fair and beneficial outcomes for those affected. In practice of course, resettlement tends to privilege the objectives of elites, is an expression of particular power relations, and typically results in distributive injustice. While in the past much of the impetus for the normalisation of resettlement came from the World Bank as the gatekeeper of development knowledge and practice, there are signs that Chinese institutions are now stepping into this role, with implications for climate-induced resettlement.

Building on decades of experience using resettlement in response to environmental degradation, to sedentarise herding communities, to accelerate urbanisation, and as a poverty alleviation strategy (Rogers and Wang, 2006; Xun and Bao, 2008; Gongbo et al., 2012; Rogers and Xue, 2015, Wilmsen and Webber, 2015; Wilmsen 2016b, Zheng et al., 2016; Habich, 2016), China's reasons for pursuing resettlement projects now extend to anticipating or avoiding the impacts of climate change. The central government's 2013 National Climate Change Adaptation Strategy lists resettlement as an adaptation action for agricultural areas and 'ecological zones' like the Loess Plateau (National Development and Reform Commission, 2013). Ningxia's experience, where 'ecological' resettlements in response to water insecurity have been carried out for decades, is being repackaged as a pilot for climate-induced resettlements. This is partly driven by a joint UK-Swiss-PRC project called Adapting to Climate Change in China, now in its second phase. Articles about Ningxia claim that resettlement is an important adaptive measure for drought (Yang et al. 2015), but it is only very recently that these projects took into account the long-term viability of resettlement sites (Zheng et al., 2016). If there are vulnerability assessments, these are done at the county level (Zheng et al., 2016), which is inadequate for understanding vulnerability or informing planning in China because of significant inequality between and within villages. The burgeoning natural hazards and disaster literature in 
China has found resettlement to result in generalised impoverishment (Chen et al. 2017) and disproportionately burdened the most vulnerable (Guo and Kapucu, 2018). Others working at the interface of poverty alleviation and disaster prevention have argued that government-led resettlement projects are adaptive because they reduce exposure to hazards, enable mobility, provide financial incentives, and improve living standards and psychological wellbeing (Lei et al., 2017). But these claims are based on data from resettlement projects that did not consider vulnerability in their planning, or changing environmental conditions over time. This same study actually found that resettlement disproportionately burdened the most vulnerable groups: the poor, people left behind, and some new migrants (Lei et al., 2017).

In what some argue is an era of climate services, where governments are seeking out actionable climate knowledge and technical, profitable solutions (Keele, in press), in China, the line between climate-induced resettlement, poverty alleviation resettlement and environment-induced resettlement is blurring. We argue that it is not sufficient to repackage existing resettlement practice as climate change adaptation, and that further interrogation of the justice implications of resettlement projects in China is needed. Resettlement projects that do not assess vulnerability, and do not consider climatic risks in the selection of resettlement sites, should not be assumed to be adaptive. We return to the question of China's central role in resettlement practice in the discussion, but in what follows we outline our analysis of multi-scalar justice in resettlement practice.

\section{Distributive justice in Chinese resettlement projects}

Resettlement projects in China occur against a backdrop of substantial inequality. China's levels of inequality are high by international standards, which reflects entrenched differences in educational opportunity, government transfers, and income from assets (Li and Sicular, 2014). Existing rural development and poverty alleviation programs have also suffered from elite capture and outright corruption (World Bank, 
2009; Park and Wang, 2010), which reminds us that varied political and economic positions exist within counties, within townships, and within villages. Thus any consideration of distributive justice in China must be attuned to inequality and its causes at multiple scales. Below we consider outcomes across scales using brief qualitative and quantitative examples from past projects. These examples illustrate how resettlement can both reinforce existing inequalities, and disrupt and reorganise inequality across multiple scales.

\section{Between households and villages}

Rogers and Xue's (2015) study of a poverty alleviation resettlement initiative in Ji County, Shanxi (a province in northern China), explores the differences between resettled and non-resettled households within one administrative village to determine whether resettlement reduces vulnerability to climate change. It shows how low income, significant debt, and smaller land allocations constrain the livelihoods of resettled households, rendering them more vulnerable to climate change than nonresettled households. The differences, however, were not just between resettled and non-resettled households, but also amongst resettled households; for example, in accessing farmland. One family had decided to resettle slightly later than others and was only allocated a very small piece of land. They were renting additional land from the village committee to bolster their resources, as were other families who received small allocations. In contrast, the village head's family had been allocated a much larger piece of land, and was renting additional farmland from another family. Access to land plays a key role in determining income from the local cash crop (apples): those with more land can plant more trees and eventually reap more profit, and this greater financial capital is used to buffer livelihoods in times of drought. Connections to local officials and access to information about the resettlement process likely played a role in the village head receiving a better deal; these factors should not be assumed to be uniform in a resettlement project. Thus distributive justice can play out both between resettled and non-resettled households, and amongst resettled households, shaped by local politics and uneven access to resources. 
If resettlement is to be used as a means of adaptation to climate change it will have long-term repercussions, yet little is known about what happens to resettled populations beyond the project cycle. Wilmsen and colleagues' study of the Three Gorges Dam resettlement is one of the few, if not only, independent assessments of the longer-term livelihood outcomes of resettlement in China. Their analysis found that resettled households suffered multiple deprivations in the period following relocation - income decline, landlessness, food insecurity and joblessness common amongst the households (McDonald et al., 2008; Wilmsen et al., 2011a; Wilmsen et al., 2011b), but eight years on livelihoods had improved - increased income, increased land holdings, less food insecurity, and improved social well-being (Wilmsen, 2016a; Wilmsen, 2018).

Aggregate improvement, however, does not equate to distributive fairness: inequality among households requires closer analysis. Between 2003 and 2011 large increases in average income were observed across all income quartiles (see Wilmsen, 2016, for more detailed presentation of data). Moreover, there was significant narrowing of the gap between the lower quartiles relative to the top quartile. This reveals three important trends. First, the bottom quartile group, as ranked in 2003, exhibited rapid income growth in the eight years following resettlement. Second, there was significant reshuffling of households between income quartiles demonstrating extreme flux in socio-economic position over time. Third, although income inequality declined between 2003 and 2011, it persisted.

A regression analysis (see Appendix 1) reveals that the incomes of particular households were less likely to rise. The characteristics of these households are as follows: they were located in Badong County, had relocated from rural villages to urban areas, had lower incomes before resettlement, had fewer working adults, had lower education, could not secure a job in an enterprise, did not borrow money and had lower social and political capital. Conversely, households that experienced the 
largest income growth had pre-existing characteristics that enabled them to take full advantage of the political-economic conditions underlying the resettlement process. For example, those with higher incomes before resettlement had greater capacity to save money and to service larger loans than poorer households. These financial buffers expanded the range of choices available when re-establishing livelihoods after resettlement. Similarly, higher education levels improved the likelihood of employment in the region's newly established enterprises. Greater political connectedness, economic security, social connections and wellbeing all increased opportunities for raising the financial constituents of livelihoods.

Broader planning processes were also at work in the Three Gorges that acted to restrict income growth for some groups while stimulating the growth of others. For example, living in a rural village subsumed by the construction of a new county town and changing hukou (household registration) status from rural to urban tended to limit income growth. Land is a resource of production for consumption and/or sale, an asset that can be rented to support migration, and a place to return to if opportunities fail or age or illness intervenes. Rural-to-urban resettlers lost that land and therefore their safety net. They were forced to seek alternative livelihoods in the urban areas in which they now lived and most did not have the skills required to secure reliable jobs. Instead, they relied on government subsidies, remittances from family members working elsewhere or manual labour in the informal labour market (see Wilmsen and van Hulten, 2017, for further discussion). Climate change-induced resettlement in China, and in other countries where fertile farmland is scarce, will likely be a rural-tourban movement (Lei et al., 2017). What the Three Gorges experience shows is that there is a need to consider the differing capacities of people to adapt to urban living.

\section{Within counties}

Within China's complex administrative hierarchy (central, provincial, prefectural, county, township, and informal governance at the village scale), the county is an increasingly powerful administrative unit, in which county officials are largely 
responsible for decision-making about project implementation. The question of which villages will be selected for particular projects based on the available funding flowing from higher levels is the responsibility of these officials. If we want to understand why certain villages are included or excluded from particular initiatives (including resettlement projects), we must understand the incentives that local officials respond to, and the political environment in which they work. This local political economy of rural China will fundamentally shape prospects for just outcomes in any climateinduced resettlements.

The example used comes from the same Shanxi poverty resettlement case discussed above. In a single township, on either side of a river valley lie two villages. Village 1 was selected for the poverty resettlement scheme, Village 2 was not. In fact, there were no future plans for resettlement schemes in Village 2, and very little investment in other infrastructure. These were poverty resettlements, hence the decision about who should participate in a poverty alleviation initiative should have been based on need, prioritising the most vulnerable. At the time of data collection (2012), Village 2 had a per capita average income of $1000 \mathrm{RMB}$ (well below the national poverty line at the time of $2300 \mathrm{RMB}$ ), with no health clinic, no schools, no transport, no shops, and no cold storage facilities or other infrastructure to support the local apple industry. It also had much lower apple production compared to neighbouring villages. Given the lack of services and entrenched poverty, it seemed a likely candidate for a resettlement project. Village 1 had comparatively higher average income (2500 RMB per capita), much higher apple production, and some services such as shops, a health clinic, and a local bus. Two resettlement projects took place within its boundaries, led by the country poverty alleviation office.

The politically-charged selection of villages for rural development initiatives in China is well documented (Smith, 2009; Heberer and Trappel, 2013; Ahlers and Schubert, 2013; Rogers, 2014). Local officials engage in impression management, or 'showcasing', meaning they are incentivised to choose more straight-forward, more 
accessible, and already more developed locations for their rural development initiatives, and to channel their somewhat limited funds into these likely 'winners'. Demonstrating wins also assists in meeting annual performance targets, which are necessary for promotion. The more distant village with entrenched poverty is therefore not an obvious candidate for poverty resettlement in the Shanxi example. This is of course an entirely rational response to the political and administrative environment in which local officials operate. In a political system where the selection of villages for projects is not based on an assessment of vulnerability (and therefore relative need) but on other political motivations, distributive fairness cannot be assured.

\section{Between counties}

Where a resettlement covers more than one county, national-level funding and planning interventions that may prioritise one county over another can also exacerbate existing inequality. In the Three Gorges Dam resettlement, key dam building activities were located in Zigui County. Tourists also flowed into the region to take organised tours of the dam and visit the resettlement villages. In comparison, Badong County was more difficult to get to and far from Yichang City, which was the origin of many of these tours. Given the high visibility of Zigui, the reconstruction of the county town was more grandiose in scale and aesthetics than Badong county town. In Zigui's county town, tree-lined boulevards funnelled visitors past colonial style buildings, a stark contrast to the utilitarian constructions in Badong.

This favouritism in the initial stages of the resettlement also extended to the State Council's plans to stimulate the regional economy. National funding and investments from eastern provinces in China were directed into Zigui County to a higher degree than Badong County. ${ }^{\mathrm{i}}$ This was partly a function of the pre-existing differences between the two counties - in particular, Zigui's more favourable terrain and location for construction and logistics - but also the efforts of Zigui's more entrepreneurial county government. While Badong's county government was simply dealing with 
building the new county town on its steep and unstable slopes ${ }^{\mathrm{ii}}$, Zigui's Development and Reform and Committee established competitive preferential policies to attract companies into its purpose-built Special Economic Zone and travelled to the east coast to promote Zigui as an investment destination. As a result, private investment flowed into Zigui, but not into Badong.

This combination of county-level politics, geography and market forces combined to affect distributive fairness at the household level. In 2003, urban households that secured employment in the new enterprises had already experienced income growth when compared to their income before resettlement (McDonald et al., 2008), and as their education levels improved and the Special Economic Zone expanded, the proportion of households accessing factory jobs and growing their incomes increased over time. Meanwhile, households resettled within Badong County did not access employment in enterprises as there were simply too few in the county. As a result, incomes in Badong dropped after resettlement and grew more slowly between 2003 and 2011 than their counterparts in Zigui (Wilmsen, 2016).

\section{Project level}

The national importance and level of scrutiny of resettlement projects varies widely, as does the capacity of local officials, which can influence distributive fairness at the project scale. In this paper we have discussed two resettlements - one infamous (Three Gorges Dam) and one relatively unknown (a poverty alleviation resettlement in Shanxi). The Three Gorges Dam resettlement received worldwide attention, even among those with a peripheral interest in China. It drew broad coverage in the popular press and generated a spike in international and domestic tourists to the region. There were plenty of research articles too and widespread condemnation from NGOs. One Chinese journalist, Dai Qing, was even jailed for her opposition. In contrast, poverty alleviation and environmental resettlement in China has garnered little attention outside of special interest groups and academics. 
We argue that notoriety has shaped inequities between these two kinds of resettlement. The Three Gorges dam was a project of national and international significance and so its resettlement received unprecedented attention. It was designed and supported by the highest level of government and a vast bureaucracy was constructed to implement its plans. There were also separate regulations promulgated to govern the Three Gorges Dam resettlement that aimed to promote the economic and social development of the region. Moreover, to fund infrastructure reconstruction and to boost this inland regional economy, the State Council co-opted China's wealthy eastern provinces and municipalities. Billions of RMB have been invested in the Three Gorges region to propel what was a relative backwater in terms of China's economic development into a destination for manufacturing and logistics ${ }^{\mathrm{iii}}$. Problems with the resettlement were dealt with swiftly and sometimes brutally: the former head of the construction bureau of Fengdu County was executed for fiscal misappropriation while another 97 bureaucrats were arrested. The political resolve to make a success of the resettlement has meant unprecedented and sustained national support for the growth of the region.

In contrast, the massive poverty resettlements that have occurred inland China over the past decade have received very little international attention. Presently, 2.4 million people are being resettled in southern Shaanxi Province, building on the experience of smaller poverty alleviation projects like the one in Ji County, Shanxi. This far exceeds the numbers displaced for Three Gorges. A different set of regulations and institutions apply to these kinds of projects, which are typically managed by county government poverty alleviation bureaus, or development and reform commissions, and in these inland provinces, fiscal and other resources can be highly constrained.

These projects are conceived of as development projects i.e. their purpose is to assist poor people, not to displace poor people in the way of mega-projects. But if they are truly conceived of as a development opportunity, the funding available to households is not sufficient: households can be left in severe debt as they struggle to raise the 
resources needed to rebuild their livelihoods. In past poverty resettlement projects, households have received 11,000 RMB (Shanxi) and 25,000 RMB (Shaanxi), while the average cost of resettlement is 79,000 RMB per household (Lo et al., 2016). Earlier projects gave as little as 5000 RMB (Rogers and Xue, 2015). While China's central government invests huge amounts of money in resettlement, and projects in recent years have significantly reduced the debt burden, there remain adverse impacts on financial capital. To some extent, these projects continue to rely on local government fiscal capacity, which varies widely (Rogers, 2016), and can affect the availability of housing subsidies and the quality of infrastructure. While there may be some additional funding from local philanthropists or agribusinesses, there is nothing like the transfer of wealth from China's eastern provinces seen in the Three Gorges Dam project.

\section{Discussion}

The examples we have provided of the lack of distributive justice remind us that resettlement projects will interact with structural drivers of inequality (class, gender, age, geography, political capital etc.) to (re)produce this inequality at multiple scales, in sometimes unexpected ways. If, like Graham et al (2015), we consider distributive and procedural justice to be intertwined, it is important to consider the ways in which these effects (on individuals and communities) might be shaped by the process of decision-making. In the case of poverty alleviation resettlement, residents may be able to choose whether they participate in a proposed resettlement project, but if they decide not to participate they are separated from their community and future government investment in their village. Further, people receive rudimentary instructions about the nature and timing of their own resettlement and have little meaningful involvement in the design or location of their new communities and homes. The space for participatory and informed decision-making in China is very limited (Lo and Wang, 2018). Similarly, the kind of values-based approach advocated elsewhere (Graham et al., 2014) has little purchase in China. People may value their 
farmland, their residences, their ancestral graves, their lifestyle, and the ongoing viability of their communities, but compensation is only ever based on calculations of commodified land, crop, and housing assets.

These questions of procedural and distributional justice highlight the politicised nature of resettlement projects. But we must look far beyond local politics to fully appreciate the prospects for just outcomes in climate-induced resettlement. Following Webber's (2016) call for critical adaptation scholarship informed by critical development studies, scholars must interrogate how hegemonic ideas of resettlement are stabilised and put into practice. Specifically, through what processes and networks is resettlement being normalised as an adaptive response to climate change impacts? This necessarily includes an analysis of the webs of actors that produce expertise and legitimise resettlement practice within and beyond China's borders. Through such an analysis we will reach a clearer understanding of the interests served through resettlement projects and the prospects for fair adaptation. Certain climate-induced resettlements may be relatively clear-cut, particularly in the case of sea-level rise and storm surges. Others, however, in response to intensified droughts, extreme temperatures or changing rainfall patterns, will require a process to weigh up the community's preferences, and the costs and benefits of relocation based on an understanding of impacts, vulnerability, and adaptive capacity. These are political decisions, and they are decisions in which many different actors have a stake, but not necessarily an equal voice.

If the prospects for fair adaptation through resettlement, at least as it is currently practiced in China, are fairly bleak, some caution is needed in the way we write and talk about climate-induced resettlement. Well-meaning advocacy such as the recent Friends of the Earth Asia-Pacific report which calls for immediate measures to identify available land and other appropriate resources for the purposes of relocating and resettling all forced climate migrants' (Friends of the Earth Asia-Pacific, 2017: 8), has the effect of de-politicising resettlement and marginalising alternative 
responses. It undermines the principle that resettlement should be avoided wherever possible. So, what alternatives are available and are they likely to have fairer outcomes than planned resettlement? In what follows we briefly identify three (certainly not mutually exclusive) alternatives: in-situ adaptation, removing barriers to migration, and cash transfers.

First, given what we know about the disruption caused by resettlement it is important to stress the potentialities of in-situ adaptation. In places we are familiar with that face higher likelihood of drought (and more severe droughts) because of climate change, there is much that can be achieved through water-saving irrigation methods, dwarfing fruit tree varieties, orchard netting, and other strategies. Chinese farms currently lose 55 percent of irrigation water through canal seepage and loss during delivery (Peng, 2011), and drip or sprinkler irrigation technologies are not yet widespread. Addressing water-use efficiency should be a central adaptive strategy for agricultural areas. Of course, climate-smart agriculture and other adaptation interventions are also political projects, with their own implications for distributive and procedural equity (Karlsson et al., 2017). As China continues to rapidly scale up its farm size through consolidating small landholdings into large entities run by powerful families, collectives or dragon-head agribusinesses, it is critical that smallholders are not further marginalised by being overlooked for new technologies and training opportunities. Nonetheless, if we take seriously the principle of resettlement as a last resort, these kinds of in-situ adaptations should be front and centre.

The second alternative is removing barriers to migration. Rarely is a migration decision solely driven by climate change impacts. People choose to stay in places highly exposed to climate change, or chose to migrate elsewhere for reasons of identity, community, lifestyle, economic opportunity, and access to services (Mortreux and Barnett, 2009). These reasons and the values that people attach to place and community would be better served by enabling migration (for those who choose to do so), than state-driven, en masse resettlement. In China, this would mean 
addressing the remaining societal and structural discrimination against holders of rural household registration in access to education, welfare, and medical care. It would also mean understanding which groups or individuals are less able to access the off-farm jobs, urban housing, and urban social networks needed to successfully migrate.

A third response is the provision of social grants in the form of cash transfers that target the vulnerable. Adaptive capacity is a multidimensional phenomenon of which economic wellbeing is one subcomponent (Below et al., 2012). Where financial capacity is lacking, social grants can provide greater liquidity so that people can draw on their own skills, networks and capacities to self-determine their responses to climate change, at a time and in a manner best suited to their individual circumstances. Broadly speaking, resettlement scholars and the leading international financial institutions regard cash payments as a flawed means to the economic recovery of resettled households. However, in the rare instance that resettlement is deemed to be the only option, cash transfers may be critical to the economic recovery of households unsuited to the new environment. Indeed, Wilmsen's (2017) study of rural households resettled to urban areas for the Three Gorges Dam demonstrates just that. Global adaptation finance, drawn primarily from those states with the greatest historic responsibility for emissions, has a role to play here.

There is a dearth of literature exploring the likely contribution of cash transfers to adaptive capacity. The limited literature that does exist suggests that cash transfers have the potential to enhance adaptive capacity (Davies et al., 2008), particularly mobility and livelihood transitions (Wood, 2011). We also find support for this alternative to resettlement in the corpus of social policy, social justice and development literatures. Although not without contention (Carter et al., 2016; Araujo et al., 2017), viewed broadly, cash transfer programmes have been shown to reduce poverty, increase employment rates, and improve education and vaccination rates (Ballard, 2013; Ferguson, 2015; Hjelm et al., 2017). Here we see the potential of cash 
transfers to bolster the economic and social determinants of adaptive capacity and enable people to exercise their own agency in ways that state-driven planned resettlement projects with uneven outcomes cannot.

\section{Conclusion}

In this article we have examined the prospects for just outcomes in planned resettlement, and argued that due to the interplay between resettlement, politics, and inequality, these prospects are relatively poor. Resettled households in the Shanxi poverty resettlement were found to be more vulnerable to climate change than nonresettled households. And, amongst resettled households those with better connections to local officials could negotiate a better deal in the resettlement process. The Three Gorges Dam resettlement demonstrated how over time there is significant reshuffling of households in terms of the socio-economic position and that those who are resettled from rural to urban areas are most likely to struggle to achieve distributive justice. Also at the Three Gorges, unequal investment in one county over another led to distributive injustice with implications at lower scales: incomes in the less favoured county dropped after resettlement and grew more slowly between 2003 and 2011 than in the county that received an influx of financial and political support. Finally, some resettlement projects receive greater resourcing and support than others because of their political significance: the notoriety of the Three Gorges Dam relative to the poverty resettlement in Shanxi shaped inequities between the two kinds of resettlements.

There appear to be limited prospects for distributive or procedural justice in Chinese resettlement projects: resettlement is a highly politicised process that produces, redistributes or exacerbates inequalities at multiple scales. Of course, these processes are not bounded by a particular territory or scale: intergovernmental relations in China are in flux, the state and private capital that enables resettlement projects flows across space, and the networks of Chinese resettlement "expertise" are increasingly mobile. While not the primary focus of this paper, future research at the intersections of 
climate justice and resettlement would do well to engage much more deeply with the politics of scale.

In 2012 Johnson (2012: 322) argued that 'among the very wide range of adaptation measures that could conceivably be used to reduce the vulnerability of affected populations, resettlement represents what is morally and politically speaking an adaptation of last resort'. Our analysis reinforces and expands on Johnson's proposition. To conclude, recognising that the resettlement industry will roll on, our pragmatic selves call for greater attention to be paid to achieving fair adaptation and avoiding maladaptation in resettlement projects by integrating vulnerability into resettlement planning, expanding opportunities for community involvement, and focusing on inequality in opportunities and outcomes. Our more idealistic selves argue that in-situ adaptation, reduced barriers to movement, and direct cash transfers have much better prospects for just outcomes. Our critical scholar selves argue that a thorough critique of the gradual legitimisation of resettlement as development, and now as climate change adaptation, is long overdue.

\section{References}

Adger, N. W. (2001) Scales of governance and environmental justice for adaptation and mitigation of climate change. Journal of International Development 13(7): 921-913.

Adger, N. W., N. W. Arnell and E. L. Tompkins (2005) Successful adaptation to climate change across scales. Global Environmental Change 15(2): 77-86.

Adger, W. N. (2006) Vulnerability. Global Environmental Change 16: 268-281.

Ahlers, A. L. and G. Schubert (2013) Strategic modelling: "Building a new socialist countryside" in three Chinese counties. China Quarterly 216:831-849.

Araujo, M. C., M. Bosch and N. Schady (2017) Can Cash Transfers Help Households Escape an Inter-Generational Poverty Trap? Cambridge: National Bureau of Economic Research, Inc.

Asian Development Bank (2012) Addressing Climate Change and Migration in Asia and the Pacific. Manila: Asian Development Bank.

Ballard, R. (2013) Geographies of development II: Cash transfers and the reinvention of development for the poor. Progress in Human Geography 37(6): 811-821.

This article is protected by copyright. All rights reserved. 
Barnett, J. and M. Webber (2009) Accommodating Migration to Promote Adaptation to Climate Change. In Policy Research Working Paper 5270. Stockholm: World Bank.

Barrett, S. (2013) Local level climate justice? Adaptation finance and vulnerability reduction. Global Environmental Change 23(6): 1819-1829.

Below, T. B., K. D. Mutabazi, D. Kirschke, C. Franke, S. Sieber, R. Siebert and K. Tscherning (2012) Can farmers' adaptation to climate change be explained by socio-economic household-level variables? Global Environmental Change 22: 223-235.

Bettini, G., S. L. Nash and G. Gioli (2016) One step forward, two steps back? The fading contours of (in)justice in competing discourses on climate migration. Geographical Journal 183(4): 348-358.

Brookings and UNHCR (2015) Guidance on protecting people from disasters and environmental change through planned relocation. Washington D.C.: Georgetown University.

Bulkeley, H (2005) Reconfiguring environmental governance: Towards a politics of scales and networks, Political Geography, 24: 875-902

Carter, M., M. Ikegami and C. Barrett (2016) Poverty Traps and the Social Protection Paradox California: Basis, University of California.

Cernea, M. M. (1997) The risks and reconstruction model for resettling displaced populations. World Development 25(10): 1569-1587.

Chen, Y. Tan, Y. and Y. Luo (2017) Post-disaster resettlement and livelihood vulnerability in rural China. Disaster Prevention and Management 26(1): 6578.

Davies, M., J. Leavy, T. Mitchell and T. Tanner (2008) Social Protection and Climate Change Adaption.Commission of Climate Change and Development November http://www.pacificdisaster.net/pdnadmin/data/original/CCCD_2008_Social_pr otection.pdf.

de Sherbinin, A., M. Castro, F. Gemenne, M. M. Cernea, S. Adamo, P. M. Fearnside, G. Krieger, S. Lahmani, A. Oliver-Smith, A. Pankhurst, T. Scudder, B. Singer, Y. Tan, G. Wannier, P. Boncour, C. Ehrhart, G. Hugo, B. Pandey and G. Shi (2011) Preparing for resettlement associated with climate change. Science 334(6055): 456-457.

Escobar, A. (1995) Encountering Development: The Making and Unmaking of the Third World. Princeton and Oxford: Princeton University Press.

Felli, R. (2013) Managing climate insecurity by ensuring continuous capital accumulation: 'Climate refugees' and 'climate migrants'. New Political Economy 18(3): 337-363.

Ferguson, J. (1994) The Anti-Politics Machine: "Development", Depoliticization and Bureaucratic Power in Lesotho. Minneapolis and London: University of Minnesota Press.

Ferguson, J. (2015) Give a Man A Fish: Reflections on the New Politics of Distribution. Durham: Duke University Press. 
Fisher, S. (2012) The emerging geographies of climate justice. In IDEAS Working Paper Series from RePEc. London School of Economics: London.

Friends of the Earth Asia-Pacific (2017) Call for Just Solutions for Climate Induced Migration in Asia Pacific: Untold Stories of People Impacted by Climate Change. George Town: Friends of the Earth Asia-Pacific.

Goldman, M. (2005) Imperial Nature: The World Bank and Struggles for Social Justice in the Age of Globalization. New Haven and London: Yale University Press.

Gongbo Tashi and J. M. Foggin (2012) Resettlement as development and progress? eight years on: Review of emerging social and development impacts of an 'ecological resettlement' project in Tibet autonomous region, China. Nomadic Peoples 16(1): 134-151.

Graham, S., J. Barnett, R. Fincher, A. Hurlimann and C. Mortreux (2014) Local values for fairer adaptation to sea-level rise: A typology of residents and their lived values in Lakes Entrance, Australia. Global Environmental Change 29: 41-52.

Graham, S., J. Barnett, R. Fincher, C. Mortreux and A. Hurlimann (2015) Towards fair local outcomes in adaptation to sea-level rise. Climatic Change 130(3): 411-424.

Guo, X. and N. Kapucu (2017) Examining the impacts of disaster resettlement from a livelihood perspective: a case study of Qinling Mountains, China. Disasters 42(2): 251-274.

Habich, S. (2016) Dams, Migration and Authoritarianism: The Local State in Yunnan. London and New York: Routledge.

Heberer, T. and R. Trappel (2013) Evaluation processes, local cadres' behaviour and local development processes. Journal of Contemporary China 22(84): 10481066.

Hjelm, L., S. Handa, J. de Hoop and T. Palermo (2017) Poverty and perceived stress: Evidence from two unconditional cash transfer programs in Zambia. Social Science \& Medicine 177: 110-117.

Johnson, C. A. (2012) Governing climate displacement: The ethics and politics of human resettlement. Environmental Politics 21(2): 308-328.

Karlsson, L., L. O. Naess, A. Nightingale and J. Thompson (2017) 'Triple wins' or 'triple faults'? Analysing the equity implications of policy discourses on climate-smart agriculture (CSA). The Journal of Peasant Studies, Online First, $1-25$.

Keele, S (in press) The business of climate services: Shifting from public to private science, Climatic Change

Kothari, U. (2005) Authority and expertise: The professionalisation of international development and the ordering of dissent. Antipode 37(3): 425-446.

Lei, Y. R., C. Finlayson, R. Thwaites, G. Q. Shi and L. J. Cui (2017) Using government resettlement projects as a sustainable adaptation strategy for climate change. Sustainability 9(8): 1-16.

This article is protected by copyright. All rights reserved. 
Levien, M. (2017) From primitive accumulation to regimes of dispossession. In The land question in India: State, dispossession and capitalist transition, eds. A. D'Costa and A. Chakraborty. Oxford: Oxford University Press.

Li, S. and T. Sicular (2014) The distribution of household income in China: Inequality, poverty and policies. The China Quarterly 217: 1-41.

Li, T. M. (2007). The Will to Improve: Governmentality, Development and the Practice of Politics. Durham and London: Duke University Press.

Lo, K. and M. Y. Wang (2018) How voluntary is poverty alleviation resettlement in China? Habitat International 73: 34-42.

Lo, K., L. Xue and M. Wang (2016) Spatial restructuring through poverty alleviation resettlement in rural China. Journal of Rural Studies 47(Part B): 496-505.

Mathur, H. M. (2015) Climate change and displacement: Learning from resettlement in the development context. Social Change 45(1): 118-130.

McAdam, J. and E. Ferris (2015) Planned relocations in the context of climate change: Unpacking the legal and conceptual issues. Cambridge Journal of International and Comparative Law 4: 137-166.

McDonald, B., M. Webber and Y. F. Duan (2008) Involuntary resettlement as an opportunity for development: The case of urban resettlers of the Three Gorges Project, China. Journal of Refugee Studies 21(1): 82-102.

Meyer Lukas, H. and D. Roser (2006) Distributive Justice and Climate Change. The Allocation of Emission Rights. In Analyse \& Kritik, 223.

Mortreux, C. and J. Barnett (2009) Climate change, migration and adaptation in Funafuti, Tuvalu. Global Environmental Change 19: 105-112.

National Development and Reform Commission (2013) Guojia shiying qihou bianhua zhanlue 国家适应气候变化战略 (National Climate Change Adaptation Strategy). Beijing: National Development and Reform Commission.

O'Brien, K. L. and R. M. Leichenko (2003) Winners and Losers in the Context of Global Change. Annals of the Association of American Geographers 93(1): 89-103.

Paavola, J. (2008) Science and social justice in the governance of adaptation to climate change. Environmental Politics 17(4): 644-659.

Paavola, J. and W. N. Adger (2006) Fair adaptation to climate change. Ecological Economics 56(4): 594-609.

Page, E. A. (2006). Climate Change, Justice and Future Generations. Cheltenham: Edward Elgar.

Park, A. and S. Wang (2010) Community-based development and poverty alleviation: An evaluation of China's poor village investment program. Journal of Public Economics 94(9-10): 790-799.

Peng, S. (2011) Water resources strategy and agricultural development in China. Journal of Experimental Botany 62(6): 1709-1713.

Popke, J., S. Curtis and D. W. Gamble (2016) A social justice framing of climate change discourse and policy: Adaptation, resilience and vulnerability in a Jamaican agricultural landscape. Geoforum 73(Supplement C): 70-80. 
Ringius, L., A. Torvanger and A. Underdal (2002) Burden Sharing and Fairness Principles in International Climate Policy. International Environmental Agreements 2(1): 1-22.

Risse, M. (2009) The right to relocation: disappearing island nations and common ownership of the earth. Ethics and International Affairs 23(3): 281-300.

Rogers, S. (2014) Betting on the strong: Local government resource allocation in China's poverty counties. Journal of Rural Studies 36: 197-206.

Rogers, S. (2016) Adaptation science and policy in China's agricultural sector. Wiley Interdisciplinary Reviews: Climate Change 7(5): 693-706.

Rogers, S. and M. Wang (2006) Environmental resettlement and social dis/rearticulation in Inner Mongolia, China. Population and Environment 28(1): 4168.

Rogers, S. and T. Xue (2015) Resettlement and climate change vulnerability: Evidence from rural China. Global Environmental Change 35: 62-69.

Schlosberg, D. (2012) Climate justice and capabilities: A framework for adaptation policy. Ethics and International Affairs 26(4): 445-461.

Schlosberg, D. and L. B. Collins (2014) From environmental to climate justice: climate change and the discourse of environmental justice. Wiley Interdisciplinary Reviews: Climate Change 5(3): 359-374.

Smith, G. (2009) Political machinations in a rural county. China Journal 62: 29-59.

TGPCC. 2011. Statistical data in the Three Gorges Reservoir Area (1992-2009). Beijing: Executive Office of Three Gorges Project Construction Committee of the State Council and the National Bureau of Statistics of China.

Thomas, D. S. G. and C. Twyman (2005) Equity and justice in climate change adaptation amongst natural-resource-dependent societies. Global Environmental Change 15: 115-124.

Vandergeest, P. (2003) Land to some tillers: Development-induced displacement in Laos. International Social Science Journal 55(175): 47-56.

Vanderheiden, S. (2008). Atmospheric Justice: A Political Theory of Climate Change. New York: Oxford University Press.

Warsaw International Mechanism Executive Committee. 2017. Task Force on Displacement. Bonn: UNFCCC.

Webber, S. (2016) Climate change adaptation as a growing development priority: Towards critical adaptation scholarship. Geography Compass 10(10): 401413.

Wilmsen, B. (2016a) After the deluge: A longitudinal study of resettlement at the Three Gorges Dam, China. World Development 84: 41-54.

--- (2016b) Expanding capitalism in rural China through land acquisition and land reforms. Journal of Contemporary China 25(101): 701-717.

Wilmsen, B. (2017) Damming China's rivers to expand its cities: the urban livelihoods of rural people displaced by the Three Gorges Dam. Urban Geography 39(3):345-366.

This article is protected by copyright. All rights reserved. 
Wilmsen, B. (2018) Is land-based resettlement still appropriate for rural people in China? A longitudinal study of displacement at the Three Gorges Dam. Development and Change, 49(1): 170-198.

Wilmsen, B. and A. van Hulten (2017) Following resettled people over time: The value of longitudinal data collection for understanding the livelihood impacts of the Three Gorges Dam, China. Impact Assessment and Project Appraisal 35(1): 94-105.

Wilmsen, B. and M. Webber (2015) What can we learn from the practice of development-forced displacement and resettlement for organised resettlements in response to climate change? Geoforum 58: 76-85.

Wilmsen, B., M. Webber and Y. Duan (2011a) Involuntary rural resettlement: Resources, strategies, and outcomes at the Three Gorges Dam, China. Journal of Environment and Development 20(4): 355-380.

Wilmsen, B., M. Webber and Y. F. Duan (2011b) Development for whom? Rural to urban resettlement at the Three Gorges Dam, China. Asian Studies Review 35(1): 21-42.

Wood, R. G. (2011) Is there a Role for Cash Transfers in Climate Change Adaptation? IDS Bulletin 42(6): 79-85.

World Bank. 2009. From poor areas to poor people: China's evolving poverty reduction agenda. Washington DC: Poverty Reduction and Economic Management Department, World Bank.

Xun, L. L. and Z. M. Bao (2008) Government, market and households in the ecological relocation process: A sociological analysis of ecological relocation in S banner. Social Sciences in China 29(1): 113-128.

Yang, J., C. Tan, S. Wang, S. Wang, Y. Yang and H. Chen (2015) Drought adaptation in the Ningxia Hui Autonomous Region, China: Actions, planning, pathways and barriers. Sustainability (Switzerland) 7: 15029-15056.

Zheng, Y., H. X. Meng, X. Y. Zhang, F. R. Zhu, Z. J. Wang, S. X. Fang, S. OpitzStapleton, J. H. Pan, Z. Y. Ma, J. M. Fan, S. B. Shi, J. R. Fan, X. L. Xie, R. Nadin and S. Kierath (2016) Social vulnerability and climate risks in three provinces: Ningxia. In Climate Risk and Resilience in China, eds. R. Nadin, S. Opitz-Stapleton and Y. L. Xu, 211-241. London and New York: Routledge.

\section{Appendix 1}

Summary of regression analysis using household real income growth per person (\%) 2003-2011 as dependent variable

Co-efficient

Explanatory variables

est.

t-stat

This article is protected by copyright. All rights reserved. 
Location, and resettler type (omitted dummy: Badong, Rural-to-Rural)

Zigui, Rural-to-Rural

$144.75^{* *}$

2.17

Zigui, Rural-to-Urban

$122.62 * * *$

3.11

Zigui, Urban-to-Urban

$88.70 * *$

2.18

Badong, Rural-to-Urban

62.58

1.45

Badong, Urban-to-Urban

$139.21 * * *$

Pre-resettlement household income pp. quartile (omitted dummy:

bottom quartile)

$2^{\text {nd }}$ Quartile

16.63

0.45

$3^{\text {rd }}$ Quartile

$-.885$

$-0.02$

Top Quartile

$-92.29 * *$

Post-resettlement household income pp. quartile (omitted dummy:

bottom quartile), 2003

$2^{\text {nd }}$ Quartile

$-144.30 * * * \quad-3.54$

$3^{\text {rd }}$ Quartile

$-251.0 * * *$

Top Quartile

$-360.28 * * * \quad-8.55$

Number in Household (2003)

$-33.22 * *$

$-2.49$

Average Household Age (2003)

$-.40$

$-0.36$

Highest educational attainment in household, 2003, (tertiary omitted)

Illiterate or primary

$-63.92$

Junior high school

$-113.71 * *$

Senior high school

$-86.32 * *$

$-2.16$

Compensation per person, RMB, 2003

.00088

0.63

Enterprise job within household, 2003-2011 (Yes=1)

$81.42 * * *$

3.3

Savings amount after resettlement, 2003

$.0010^{*}$

1.86

Borrowing amount, 2003-2011

$.00049 * * *$

2.75

Index of socio-political capital, 2003 (range: -9 to 9, positive better)

$9.18^{* *}$

2.5

Constant

$624.00 * * *$

5.96

Sample size $=278$

$\mathrm{R}^{2}=0.4011$

Notes: $* * *$, and $* * *$ denotes the estimated co-efficient is significantly different from zero at the $\pm=0.1,0.05$ and 0.01 levels, respectively. Observations where income growth was less than $-20 \%$ and

This article is protected by copyright. All rights reserved. 
greater than $1300 \%$ were excluded as outliers. Observations missing one data point or more were omitted.

Source: Wilmsen (2016a)

\footnotetext{
${ }^{\mathrm{i}}$ GDP per capita in Badong was 4,581 RMB in 2004 and 8,295 in 2009. GDP per capita in Zigui was 6,041 RMB in 2004 and 11,464 RMB in 2009 (TGPCC 2011)

ii The centre of the county town had to be moved three times due to the risk of landslides.

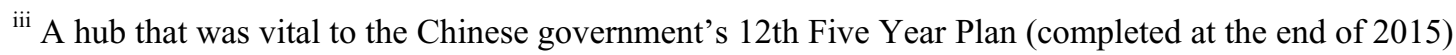
(Zigui Reform and Development Commission, 11th September 2012). According to the Zigui Reform and Development Commission, the area covers some 40,000 mu (around $2667 \mathrm{ha}$ ), costs around 8 billion RMB and increases transport capacity from 80 to 111 million metric tonnes.
} 


\section{University Library}

\section{- M M I N E R VA A gateway to Melbourne's research publications}

Minerva Access is the Institutional Repository of The University of Melbourne

Author/s:

Wilmsen, B;Rogers, S

Title:

Planned resettlement to avoid climatic hazards: What prospects for just outcomes in China?

Date:

2019-07-22

Citation:

Wilmsen, B. \& Rogers, S. (2019). Planned resettlement to avoid climatic hazards: What prospects for just outcomes in China?. ASIA PACIFIC VIEWPOINT, 60 (2), pp.118-131. https://doi.org/10.1111/apv.12232.

Persistent Link:

http://hdl.handle.net/11343/286896 